\title{
UPAYA MENINGKATKAN HASIL BELAJAR SISWA DENGAN MENGGUNAKAN MODEL PEMBELAJARAN COOPERATIVE LEARNING TIPE COURSE REIVEW HORAY PADA MATA PELAJARAN IPA DI KELAS IV SD SWASTA ST. PETRUS MEDAN TAHUN PEMBELAJARAN 2018/2019
}

\author{
EKA SRINAITA YAPULINA TARIGAN \\ (PGSD FKIP UNIVERSITAS KATOLIK SANTO THOMAS)
}

\begin{abstract}
The research used is Classroom Action Research (CAR) which aims to determine the improvement of student learning outcomes by using the Course Reivew Horay type of cooperative learning model in science subjects with the material of efforts to balance and preserve natural resources in their environment in private IV-A elementary school St. Petrus Medan Learning Year 2018/2019. Subjects in this study were students of grade IV-A Elementary School Private St. Petrus Medan Learning Year 2018/2019 totaling 28 students, consisting of 14 female students and 14 male students. The object in this study is Classroom Action Research (CAR) by applying two cycles, namely cycle I and cycle II which includes planning, implementation, observation, and reflection.

The results of this study indicate an increase in student learning outcomes in science subjects with the material of efforts to balance and preserve natural resources in their environment in class IV-A Elementary School of Private St. Petrus Medan Learning Year 2017/2018. This is evident from the results of the research that has been done on the students' pre-test scores that are complete only 1 student or $3.57 \%$ while the students who are not complete are 27 students or $96.43 \%$, then continued the research in the first cycle of students who got complete scores only 15 students or $53.58 \%$ of students who did not complete as many as 13 students or $46.42 \%$ then experienced an increase in the first cycle compared to the pretest. In the implementation of the first cycle, it still does not meet the predetermined completeness category. Then continued the research in the second cycle, namely students who got complete scores as many as 25 students or $89.29 \%$ while students who did not complete only 3 students or $10.71 \%$ then experienced an increase in the second cycle compared to the first cycle and have fulfilled the predetermined completeness . Furthermore, the teacher's activities on observation cycle I gained an average of $62 \%$ and in the second cycle increased to $84 \%$. While the activities of students in the learning process obtain an average of 70 and in cycle II has increased to 80 .

Thus it can be concluded by using the Course Reivew Horay type of cooperative learning model on natural science subjects in the effort to balance and preserve natural resources in their environment in class IV-A SD St. Petrus Medan can improve student learning outcomes. So it is recommended for further learning to use it.
\end{abstract}

Keywords: Student Learning Outcomes, Natural Science Course, Reivew Horay Cooperative Course Type. 


\section{PENDAHULUAN}

\section{Latar Belakang Masalah}

Pendidikan adalah usaha sadar dan terencana untuk mewujudkan suasana pembelajaran agar peserta didik secara aktif mengembangkan potensi dirinya. Pendidikan mempunyai peranan sangat penting dalam kehidupan manusia, karena melalui pendidikan seseorang dapat mengembangkan bakat, minat dan keterampilan yang ada dalam dirinya. Menurut Undang-undang No. 20 Tahun 2003 tentang Sistem Pendidikan Nasional pasal 1 secara tegas dinyatakan bahwa:

Pendidikan adalah usaha sadar dan terencana untuk mewujudkan suasana belajar dan proses pembelajaran agar siswa secara aktif mengembangkan potensi dirinya untuk memiliki kekuatan spiritual keagamaan, pengendalian diri, kepribadian, kecerdasan, akhlak mulia, serta keterampilan yang diperlukan dirinya, masyarakat, bangsa dan negara (Depdiknas, 2003: 1).

Undang-undang di atas menjelaskan bahwa pendidikan dilaksanakan untuk mengembangkan potensi siswa dalam mewujudkan suasana belajar dan proses pembelajaran. Tahap pendidikan mulai dari jenjang pendidikan dasar, pendidikan menengah dan pendidikan tinggi diberikan kepada siswa sesuai dengan tingkat perkembangan siswa, tujuan yang akan dicapai, dan kemampuan yang dikembangkan.

Masalah pendidikan erat kaitannya dengan proses belajar mengajar di sekolah dan keadaan siswa. Proses pembelajaran di sekolah diharapkan dapat mengembangkan segala potensi yang dimiliki siswa dan mengarahkan siswa untuk menjadi orang yang berguna serta memiliki pengetahuan luas akan segala hal. Proses pembelajaran akan berjalan dengan sia-sia, apabila tidak diikuti oleh perubahan dalam sistem dan cara mengajar guru di kelas. Rendahnya tingkat pendidikan di Indonesia tidak hanya disebabkan oleh siswa itu sendiri, tetapi guru juga memberikan peranan penting dalam 
hal ini. Selain itu diperlukan cara mengajar yang dapat mengaktifkan seluruh siswa, tidak hanya sebagian siswa saja.

Keberhasilan pembelajaran dapat dilihat dari kualitas siswa. Apabila siswa mampu menguasai apa yang akan pelajari sesuai dengan tujuan pembelajaran yang diharapkan maka dapat dipastikan keberhasilan pembelajaran telah tercapai. Cara untuk mencapai hal tersebut tidak terlepas dari peran serta guru untuk menciptakan suasana belajar yang kondusif, sehingga dapat meningkatkan pemahaman siswa tentang materi yang akan dipelajari khususnya dalam mata pelajaran Ilmu Pengetahuan Alam.

Ilmu Pengetahuan alam (IPA) merupakan salah satu mata pelajaran yang terdapat di dalam struktur kurikulum pendidikan di tingkat SD/MI dan SMP/MTs yang dimaksudkan agar siswa dapat mengenal, menyikapi, dan mengapresiasikan ilmu pengetahuan dan teknologi, serta dapat menanamkan kebiasaan berfikir dan berprilaku ilmiah yang kritis, kreatif, dan mandiri.

Berbagai upaya telah dilakukan oleh Pemerintah untuk meningkatkan mutu pendidikan dan Pembelajaran IPA, khususnya di SD yaitu memberikan pelatihan kepada guru SD salah satunya tentang mata pelajaran IPA, seperti pelatihan tentang pemilihan metode atau model yang sesuai dengan pembelajaran dan materinya. Oleh karena itu, sangat diperlukan metode atau model pembelajaran yang sesuai dengan materinya. Pembelajaran merupakan satu cara melaksanakan metode atau model yang dipilih.

Kenyataannya, berdasarkan hasil observasi pada pembelajaran IPA di kelas IVA SD Swasta St. Petrus Medan diperoleh fakta bahwa aktivitas belajar siswa masih rendah karena guru belum menumbuhkan kerjasama antar siswa seperti membentuk kelompok-kelompok kecil saat pembelajaran sehingga sikap sosial antar siswa masih kurang. Guru lebih banyak menggunakan cara belajar yang bersifat pembelajaran 
konvensional, seperti masih seringnya diterapkan metode ceramah dan kurang diterapkannya cara belajar lain yang bervariasi sehingga kemampuan berfikir siswa kurang dikembangkan. Tidak adanya dorongan atau motivasi yang menarik siswa agar lebih aktif saat mengikuti pembelajaran. Hal ini disebabkan guru kurang melibatkan siswa secara aktif dalam proses pembelajaran sehingga pembelajaran menjadi membosankan dan pembelajaran menjadi kurang bermakna akibatnya tujuan pembelajaran tidak akan tercapai dan siswa memiliki hasil belajar yang rendah.

Pembelajaran yang masih berpusat pada guru masih sering terjadi di kelas IVA SD Swasta St. Petrus terutama pada mata pelajaran IPA sehingga pembelajaran ini akan berjalan dengan satu arah saja, jika pembelajaran berjalan satu arah maka interaksi antara guru dengan siswa, siswa dengan siswa akan kurang sedangkan dalam pembelajaran seharusnya antara pendidik dan peserta didik harusada interaksi. Suasana belajar yang monoton karena guru hanya menjelaskan materi pelajaran dan siswa mendengarkan, hal ini menyebabkan siswa cenderung merasa bosan dan jenuh saat proses pembelajaran, dan masih banyak siswa yang merasa malu atau tidak mau ketika diminta mengungkapkan pendapatnya.

Data hasil belajar siswa diperoleh melalui observasi dan studi dokumentasi nilai UTS, semester ganjil pada mata pelajaran IPA tahun pelajaran 2016/2017 dan $2017 / 2018$. 
Nilai UTS Semester Ganjil Pembelajaran IPA di Kelas IV-A SD Swasta St. Petrus

Tahun Pelajaran 2016/2017 dan 2017/2018

\begin{tabular}{|l|l|l|l|l|l|}
\hline No & $\begin{array}{l}\text { Tahun } \\
\text { Ajaran }\end{array}$ & KKM & Nilai & $\begin{array}{l}\text { Jumlah } \\
\text { Siswa }\end{array}$ & Persentasi \\
\hline 1 & $2016 / 2017$ & 75 & $\leq 75$ & 38 orang & $97,4 \%$ \\
\cline { 3 - 6 } & 75 & $\geq 75$ & 1 orang & $2,6 \%$ \\
\cline { 2 - 6 } & Jumlah & & 39 orang & $100 \%$ \\
\hline 2 & $2017 / 2018$ & 75 & $\leq 75$ & 39 orang & $88,63 \%$ \\
\cline { 3 - 6 } & & 75 & 275 & 5 orang & $11,36 \%$ \\
\cline { 2 - 6 } & Jumlah & & 44 orang & $100 \%$ \\
\hline
\end{tabular}

Berdasarkan tabel di atas pada tahun ajaran 2017/2018 diketahui bahwa dari 39 orang siswa yang ada di kelas IV-A SD Swasta St. Petrus Medan, 38 orang siswa $(97,4 \%)$ dinyatakan belum tuntas dan 1 orang siswa $(2,6 \%)$ dinyatakan tuntas atau memenuhi Kriteria Ketuntasan Minimal yang ditentukan yaitu 75 dan nilai rata-rata kelas hanya mencapai 53,9. Pada tahun ajaran 2017/2018diketahui bahwa dari 44 orang siswa yang ada di kelas IV-A SD Swasta St. Petrus Medan, 39 orang siswa $(88,63 \%)$ dinyatakan belum tuntas dan 5 orang siswa $(11,36 \%)$ dinyatakan tuntas atau memenuhi Kriteria Ketuntasan Minimal yang ditentukan yaitu 75 dan nilai rata-rata kelas hanya mencapai 55,28.Melihat fakta-fakta yang telah dituliskan tersebut, maka perlu diadakan perbaikan pembelajaran.

Salah satu upaya yang dapat dilakukan guru guna dapat meningkatkan mutu pendidikan melalui peningkatan aktivitas dan hasil belajar siswa, yaitu dengan menggunakan berbagai model pembelajaran yang efektif diterapkan oleh guru-guru kreatif. Salah satu model yang cukup efektif untuk menunjang keberhasilan belajar 
siswa adalah model pembelajaran kooperatif. Model pembelajaran yang dapat meningkatkan aktivitas, kerjasama, dan menyajikan banyak soal adalah model Cooperative Learning tipe Course Review Horay (CRH).

Cooperative Learning merupakan strategi belajar dengan sejumlah siswa sebagai anggota kelompok kecil yang tingkat kemampuannya berbeda, dalam menyelesaikan tugas kelompoknya setiap anggota kelompok harus saling bekerja sama dan saling membantu untuk memahami materi pelajaran Isjoni (2011: 12). Model pembelajaran yang menyenangkan dapat meningkatkan motivasi siswa untuk belajar dengan sungguh-sungguh. Jika siswa sudah termotivasi untuk belajar, maka akan mudah bagi guru untuk mentransfer pelajaran kepada siswa dan siswa pun akan lebih mudah menerima dan menyerap materipelajaran. Salah satu tipe dari pembelajaran kooperatif yaitu Course Review Horay.

Course Review Horay merupakan salah satu model pembelajaran yang dapat mendorong siswa untuk ikut aktif dalam pembelajaran. Pembelajaran Course Review Horay dicirikan oleh struktur tugas, tujuan, dan penghargaan kooperatif yang melahirkan sikap ketergantungan yang positif diantara sesama siswa, penerimaan terhadap perbedaan individu dan mengembangkan ketrampilan bekerja sama antar kelompok. Dalam penerapan model pembelajaran ini, masalah disajikan dengan permainan yang menggunakan kartu berisi kotak yang telah dilengkapi dengan nomor soal dan siswa/kelompok yang paling dahulu mendapatkan tanda benar berbentuk garis vertikal, horizontal, atau diagonal langsung berteriak "horay" atau yel-yel lainnya.

Sohiman (2016: 54). Model pembelajaran kooperatif tipe course review horay dapat membuat siswa dengan mudah menyerap konsep-konsep yang dipelajari, sebab siswa terjun langsung dalam memecahkan masalah dalam belajar 
Model pembelajaran Kooperatif tipe Course Review Horay sangat cocok untuk digunakan pada mata pelajaran IPA pada materi upaya keseimbangan dan pelestarian sumber daya alam di lingkungannya karena materi ini membahas beberapa pokok materi karena ketika siswa mulai merasa bosan maka dapat diselingi sedikit hiburan sehingga suasana tidak menegangkan dan karena model pembelajaran cooperative tipe course review horay membagi siswa dalam kelompok-kelompok kecil sehingga siswa dapat memecahkan masalah bersama terkait materi pembelajaran dan terjalin hubungan kerjasama ketika terjalin kerjasama maka semangat dalam diri siswa akan meningkat.

Penelitian yang menggunakan model pembelajaran Kooperatiftipe Course Review Horay pada mata pelajaran IPA juga telah dilakukan oleh Nurdewi Yusnita (2016 ) yang berjudul Meningkatkan Minat Belajar Siswa Pada Mata Pelajaran IPA Melalui Model Course Reviev Horaydi Kelas IV SD Negeri 101797 Deli Tua T.A 2016/2017. Minat belajar siswa mengalami peningkatan.

Berdasarkan latar belakang di atas, peneliti tertarik untuk melakukan penelitian dengan judul "Upaya Meningkatkan Hasil Belajar Siswa Dengan Menggunakan Model Pembelajaran Cooperative Learning Tipe Course Reivew Horay Pada Mata Pelajaran IPA di Kelas IV SD Swasta St. Petrus Medan Tahun Pembelajaran 2018/2019”.

\section{Identifikasi Masalah}

Berdasarkan latar belakang masalah di atas, maka permasalahan yang dapat diidentifikasi sebagai berikut:

1. Guru kurang melibatkan siswa secara aktif dalam proses pembelajaran sehingga proses pembelajaran masih berpusat pada guru

2. Rendahnya hasil belajar siswa

3. Guru masih menggunakan metode konvensional 


\section{Batasan Masalah}

Berdasarkan latar belakang dan identifikasi masalah di atas, maka yang menjadi batasan masalah dalam penelitian ini adalah "Upaya Meningkatkan Hasil Belajar Siswa Dengan Menggunakan Model Pembelajaran Kooperatif Tipe Course Reivew Horay Pada Mata Pelajaran IPA Materi upaya keseimbangan dan pelestarian sumber daya alam di lingkungannya di Kelas IV-A SD Swasta St. Petrus Medan Tahun Pembelajaran 2018/2019”.

\section{Rumusan Masalah}

Berdasarkan pembatasan masalah tersebut, dapat dirumuskan masalah penelitian tindakan kelas sebagai berikut:

1. Apakah dengan menggunakan model Pembelajaran Kooperatif Tipe Course Reivew Horay dapat meningkatkan hasil belajar siswa pada mata pelajaran IPA materi upaya keseimbangan dan pelestarian sumber daya alam di lingkungannya di Kelas IV-A SD Swasta St. Petrus Medan Tahun Pembelajaran 2018/2019?

2. Bagaimanakah proses pembelajaran IPA materi upaya keseimbangan dan pelestarian sumber daya alam di lingkungannya melalui penerapan model Pembelajaran Kooperatif Tipe Course Reivew Horay di Kelas IV-A SD Swasta St. Petrus Medan Tahun Pembelajaran 2018/2019?

\section{Tujuan Penelitian}

Adapun tujuan dari penelitian tindakan kelas ini yaitu:

1. Untuk meningkatkan hasil belajar siswa dengan menggunakan model Pembelajaran Kooperatif Tipe Course Reivew Horay pada mata pelajaran IPA tentang upaya keseimbangan dan pelestarian sumber daya alam di lingkungannya di Kelas IV-A SD Swasta St Petrus Medan Tahun Pembelajaran 2018/2019 
2. Untuk mengetahui proses penerapan model Pembelajaran model Pembelajaran Kooperatif Tipe Course Reivew Horay pada materi upaya keseimbangan dan pelestarian sumber daya alam di lingkungannya di Kelas IV SD Swasta St Petrus Medan Tahun Pembelajaran 2018/2019.

\section{Manfaat Penelitian.}

Adapun manfaat yang diharapkan dari penelitian yang dilaksanakan di SD Swasta St. Petrus Medan adalah:

1. Bagi siswa

Untuk meningkatkan hasil belajar siswa pada mata pelajaran IPA

\section{Bagi Guru}

1) Model Cooperative Learning tipe Course Review Horay sebagai masukan dalam memperluas pengetahuan dan wawasan bagi guru pembelajaran, terutama dalam rangka meningkatkan aktivitas dan hasil belajar siswa dalam pembelajaran pelajaran IPA

2) Penerapan model Cooperative Learning tipe Course Review Horay akan memberikan suatu alternatif model pembelajaran yang dapat diterapkan dalam pembelajaran.

3) Untuk membantu guru dalam mengenal berbagai model pembelajaran.

3. Bagi Sekolah

1) Sebagai pertimbangan bagi sekolah dalam meningkatkan kualitas proses belajar mengajar, khususnya mata pelajaran IPA mengenai upaya keseimbangan dan pelestarian sumber daya alam di lingkungannya.

2) Meningkatkan kinerja sekolah melalui peningkatan profesionalisme pendidik. 


\section{Bagi Peneliti}

1) Hasil penelitian ini sebagai bahan informasi seberapa besar peningkatan hasil belajar IPA melalui penggunaan Cooperative Learning tipe Course Review Horay

2) Memberikan wawasan mengenai penerapan model pembelajaran yang inovatif, khususnya dalam meningkatkan hasil belajar siswa dalam pelajaran IPA.

\section{METODOLOGI PENELITIAN}

\section{Pendekatan dan Metode penelitian}

Pendekatan yang digunakan dalam penelitian ini adalah pendekatan campuran. Pendekatan campuran yang dimaksudkan adalah pendekatan yang menggunakan dua metode, pendekatan yang dimaksud adalah pendekatan kuantitatif dan kualitatif. Penggunaan dua metode ini dianggap lebih memberikan pemahaman yang lebih baik dan lengkap tentang permasalahan penelitian dari pada menggunakan satu metode saja. Metode yang digunakan adalah metode penelitian tindakan kelas. Penelitian tindakan kelas merupakan penelitian praktis yang dilakukan oleh guru untuk memperbaiki proses belajar mengajar baik dari alat, media, sumber, metode, strategi, maupun model yang digunakan guru tersebut.

Jenis penelitian ini bertujuan untuk memperbaiki proses pembelajaran dalam meningkatkan hasil belajar siswa dalam pelajaran IPA pada pada materi upaya keseimbangan dan pelestarian sumber daya alam di lingkungannya menggunakan model Cooperative Learning tipe Course Reivew Horay di kelas IV-A SD Swasta St. Petrus Medan tahun pembelajaran 2018/2019. 


\section{Tempat dan Waktu Penelitian}

\section{Tempat Penelitian}

Penelitian tindakan kelas ini dilakukan di kelas IV SD Swasta St. Petrus Medan, pada semester ganjil tahun pembelajaran 2018/2019 sebanyak dua siklus. Waktu pelaksanaan tindakan kelas yang berupa tabel 3.1. Adapun alasan peneliti memilih lokasi penelitian ini adalah:

1. Sekolah tersebut bersifat terbuka menerima mahasiswa yang ingin melakukan penelitian

2. Belum ada peneliti yang melakukan penelitian dengan menerapkan model Cooperative Learning tipe Course Review Horay di sekolah tersebut.

3. Peneliti sangat tertarik untuk meneliti permasalahan yang ada pada sekolah tersebut dan berniat buntuk membantu siswa mencapai hasil belajar yang maksimal.

4. Hasil belajar pada mata pelajaran IPA yang masih rendah.

\section{Waktu Penelitian}

Penelitian ini dilakukan pada semester ganjil tahun pembelajaran 2018/2019. Waktu pelaksanaan penelitian ini dilakukan pan bulan Juni sampai bulan Agutus 2018.

\section{Subjek dan Objek Penelitian}

\section{Subjek Penelitian}

Subjek dalam penelitian ini adalah siswa-siswi kelas IV-A SD Swasta St. Petrus medan, pada semester ganjil tahun pembelajaran 2018/2019 dengan jumlah siswa 28 orang, 14 orang laki-laki dan 14 orang perempuan. Usia siswa di kelas ini berkisar 9-10 tahun dengan tingkat kecerdasan yang heterogen.

\section{Objek Penelitian}

Hasil belajar siswa pada mata pelajaran IPA menggunakan model pembelajaran Kooperatif tipe Course Review Horay. 


\section{Jenis dan Sumber Data}

\section{Jenis Data}

Jenis penelitian ini meliputi metode kualitatif dan kuantitatif.

a. Kualitatif yaitu penelitian tentang riset yang bersifat deskriptif dan cenderung menggunakan analisis dengan tujuan untuk mendeskripsikan aktivitas guru dan siswaselama proses pembelajaran.

b. Kuantitatif yaitu suatu penelitian yang memberikan nilai berupa angka pada aktifitas guru dan siswa selama penelitian.

\section{Sumber Data}

Sumber data yang diperlukan berasal dari tiga sumber yaitu:

a. Guru

Dalam penelitian ini, peneliti mendapatkan informasi dari guru wali kelas IV-A SD Swsta St. Petrus medan, yang dimana peneliti mendapatkan informasi melalui wawancara dan observasi.

b. Sekolah

Sekolah merupakan tempat dimana peneliti akan melakukan penelitian. Selama penelitian berlangsung, sekolah merupakan tempat untuk mendapatkan data-data yang dibutuhkan peneliti.

c. Dokumen daftar nilai pembelajaran IPA IV-A SD Swsta St. Petrus Medan.

\section{Teknik dan Alat Pengumpulan Data}

\section{Observasi}

Observasi merupakan teknik mengumpulkan data dengan cara mengamati setiap kegiatan yang sedang berlangsung. Observasi juga berhubungan dengan kegiatan guru dan siswa. 


\section{Lembar Observasi Kegiatan Guru}

Lembar observasi pada aktivitas guru digunakan untuk melihat pelaksanaan pembelajaran yang diadakan guru di dalam kelas selama proses pembelajaran berlangsung dengan menggunakan model Cooperative tipe Course Reviev Horay (CRH). Penetapan skor untuk lembar observasi pada aktivitas guru menggunakan skala likert. Sugiyono (2016: 93) jawaban setiap instrument yang menggunakan skala likert mempunyai gradasi dari sangat positif sampai sangat negatif.

\section{Lembar Observasi Aktivitas Siswa}

Observasi kegiatan siswa digunakan untuk melihat bagaimana aktivitas maupun kegiatan yang dilakukan siswa selama mengikuti proses pembelajaran. Dalam melakukan observasi di kegiatan siswa dibantu juga oleh observer dengan tujuan untuk memperoleh data. Penetapan skor untuk lembar observasi untuk aktivitas siswa menggunakan skla likert. Sugiyono (2016: 93) jawaban setiap instrument yang menggunakan skala likert mempunyai gradasi dari sangan positif sampai sangat negatif.

\section{Tes}

Tes merupakan alat untuk mengukur kemampuan dasar dan pencapaian atau prestasi Arikunto (2010:266). Dari tes peneliti dapat mengetahui kemampuan siswa dengan cara menjawab soal-soal yang berhubungan dengan materi bagian-bagian tumbuhan dan yang hanya dibatasi pada aspek mengingat (C1), memahami (C2), dan menerapkan (C3), menganalisis (C4) untuk tes yang digunakan sebagai alat pengumpulan data

\section{Dokumentasi}

Dokumentasi dilaksanakan dengan menyertakan dokumen yang berkaitan seperti silabus, RPP, dsb beserta gambar atau foto pada saat dilaksanakan penelitian. 


\section{Uji Validitas Data dan Reliabilitas}

\section{Uji Validitas}

Sebelum instrumen diuji cobakan, terlebih dahulu yang dilakukan peneliti adalah validitas terhadap tes instrumen soal berbentuk pilihan berganda.

Untuk mengetahui validitas dari soal tersebut maka digunakan rumusan sebagai berikut:

$$
r_{x y}=\frac{N \sum x y-\left(\sum x\right)\left(\sum y\right)}{\sqrt{\left\{\sum x^{2}-\left(\sum x^{2}\right)\right\}\left\{N \sum y^{2}-\left(\sum y\right)^{2}\right)}}
$$

Keterangan :

$r_{x y}=$ Koefisien korelasi antara variable $\mathrm{X}$ dan $\mathrm{Y}$

$\mathrm{N} \quad$ = Banyaknya subjek pengikut

$\sum x y=$ Jumlah perkalian $\mathrm{x}$ dan $\mathrm{y}$

$\mathrm{X}=$ Nilai pembanding

$\mathrm{Y}=$ = Nilai dari instrument yang akan dicari validitasnya

\section{Uji Reliabilitas}

Untuk menguji reliabilitas tes, maka digunakan KR-20 dengan rumusan sebagai berikut:

$\mathrm{r}_{11}=\left(\frac{n}{n-1}\right)\left(\frac{\mathrm{s} 2-\sum p q}{s 2}\right) \ldots \ldots \ldots \ldots \ldots \ldots \ldots$ (Arikunto, $\left.2016: 115\right)$

Keterangan :

$$
\begin{array}{ll}
\mathrm{r}_{11} & =\text { reliabilitas tes secara keseluruhan } \\
p & =\text { proporsi subjek yang menjawab item dengan benar } \\
\mathrm{q} & =\text { proporsi subjek yang menjawab item dengan salah }(\mathrm{q}=1-p) \\
\sum p \mathrm{q} & =\text { jumlah hasil perkalian antara } p \text { dan } \mathrm{q}
\end{array}
$$




$$
\begin{array}{ll}
\mathrm{N} & =\text { banyaknya item } \\
\mathrm{S} & =\text { standar deviasi dari tes( standar deviasi adalah akar varians) } \\
& \text { Kategori Hasil Uji Reliabilitas }
\end{array}
$$

\begin{tabular}{|c|l|l|}
\hline No & \multicolumn{1}{|c|}{ Koefisien Korelasi } & \multicolumn{1}{|c|}{ Kualifikasi } \\
\hline 1 & $0,80<\mathrm{r}_{\mathrm{xy}} \leq 1,00$ & Sangat tinggi \\
\hline 2 & $0,60<\mathrm{r}_{\mathrm{xy}} \leq 0,80$ & Tinggi \\
\hline 3 & $0,40<\mathrm{r}_{\mathrm{xy}} \leq 0,60$ & Cukup \\
\hline 4 & $0,20<\mathrm{r}_{\mathrm{xy}} \leq 0,40$ & Rendah \\
\hline 5 & $\mathrm{r}_{\mathrm{xy}} \leq 0,40$ & Sangat rendah \\
\hline
\end{tabular}

\section{Analisis Data}

Analisis data merupakan sebuah cara untuk mengolah data menjadi informasi agar mudah dipahami dan bermanfaat untuk solusi permasalahan, terutama hal yang berkaitan dengan penelitian.

Penelitian ini mengkaji data dalam dua jenis yaitu data kuantitatif yang diperoleh dari test siswa dan data kualitatif yang diperoleh dari keterangan dan komentar lembar observasi guru dan teman sejawat.

\section{Hasil Pelaksanaan Pembelajaran}

Untuk menganalisis data hasil pelaksanaan pembelajaran dengan menggunakan model pembelajaran Cooperative tipe Course Reviev Horay maka analisisnya sebagai berikut:

a. Aktivitas guru

Untuk mengetahui pelaksanaan pembelajaran aktivitas guru digunakan rumus:

$$
\text { Nilai }=\frac{\text { Total Skor }(\text { perolehan })}{\text { Skor Maksimal }} \times 100 \%
$$


Kriteria Penilaian dalam Pelaksanaan Pembelajaran Guru

\begin{tabular}{|c|c|}
\hline Kriteria Penilaian & Keterangan \\
\hline $\mathrm{A}=81-100$ & Baik sekali \\
\hline $\mathrm{B}=61-80$ & Baik \\
\hline $\mathrm{C}=41-61$ & Cukup \\
\hline $\mathrm{D}=21-40$ & Kurang \\
\hline $\mathrm{E}=0-20$ & Sangat Kurang \\
\hline
\end{tabular}

Sumber: Saur Tampubolon2014:35

b. Aktivitas siswa

Untuk mengetahui pelaksanaan pembelajaran aktivitas siswa, dengan menggunakan rumus:

Nilai $=\frac{\text { Total Skor }(\text { perolehan })}{\text { Skor Maksimal }} \times 100$

Kriteria Penilaian dalam Pelaksanaan Pembelajaran Siswa

\begin{tabular}{|c|c|}
\hline Kriteria Penilaian & Keterangan \\
\hline $80-100$ & Baik sekali \\
\hline $70-79$ & Baik \\
\hline $60-69$ & Cukup \\
\hline $50-59$ & Kurang \\
\hline $0-49$ & Gagal \\
\hline
\end{tabular}

Sumber: Syah 2017: 151 


\section{Ketuntasan Hasil Belajar Siswa}

\section{Ketuntasan Individual}

Ketuntasan individual yaitu dapat dikatakan tuntas belajar jika proporsi jawaban benar siswa mencapai nilai KKM yang ditetapkan sekolah yaitu memperoleh nilai 75. Rumus untuk menghitung ketuntasan individu adalah sebagai berikut:

$\mathrm{KB}=\frac{\mathrm{T}}{\mathrm{Tt}} \mathrm{X} 100$ (Trianto, 2016: 241)

Dengan keterangan sebagai berikut:

$K B=$ Ketuntasan belajar

$\mathrm{T}=$ Jumlah skor yang diperoleh siswa

$T_{t}=$ Jumlah skor total

\section{Ketuntasan Klasikal}

Ketuntasan klasikal dapat dikatakan tuntas belajar jika di dalam kelas tersebut terdapat $75 \%$ siswa yang sudah tuntas belajarnya. Rumusan untuk menghitung ketuntasan klasikal adalah sebagai berikut :

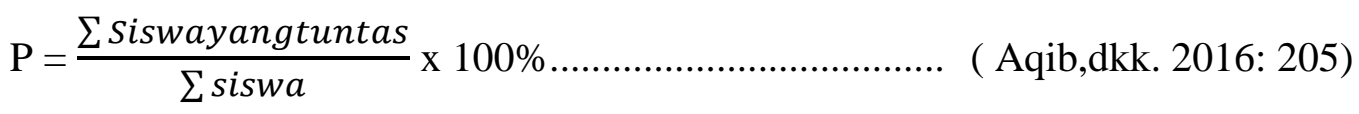

Dengan keterangan sebagai berikut:

$\mathrm{P}=$ Ketuntasan klasikal hasil observasi

\section{Penilaian Rata-Rata}

Peneliti akan menjumlahkan nilai siswa, selanjutnya dibagi dengan jumlah siswa tersebut sehingga diperoleh nilai rata-rata. Nilai rata-rata ini dapat diperoleh menggunakan rumus sebagai berikut: 
$\mathrm{X}=\frac{\sum X}{N}$ ( Sudjana, 2016: 109)

Keterangan:

$\mathrm{X}=$ Nilai rata-rata

$\sum \mathrm{X}=$ Jumlah seluruh skor

$\mathrm{N}$ =Banyaknya objek

\section{Indikator Kinerja Penelitian}

Penelitian dikatakan berhasil apabila dilakukan tindakan perbaikan kualitas pembelajaran. Indikator yang ingin dicapai dalam penelitian ini adalah meningkatkan hasil belajar IPA kelas IV-A SD St. Petrus Medan.

1. Indikator keberhasilan hasil belajar secara klasikal minimal $75 \%$ dari jumlah siswa mencapai $\mathrm{KKM}=75$.

2. Indikator keberhasilan kualitas keaktifan guru pada saat proses pembelajaran berlangsung minimal $75 \%$ dengan cara mengukur dari hasil observasi kinerja guru dalam penerapan model Cooperative tipe Course Reviev Horay (CRH)

3. Indikator keberhasilan aktivitas siswa pada saat proses pembelajaran berlangsung minimal $75 \%$ dengan cara mengukur dari hasil observasi kinerja siswa dalam penerapan model Cooperative tipe Course Reviev Horay (CRH)

\section{Prosedur Penelitian}

Desain penelitian yang digunakan dalam penelitian ini adalah Penelitian Tindakan Kelas (PTK) dengan model desain penelitian yang dikemukakan oleh Arikunto (2014: 34) dalam melaksanakan PTK terdapat empat tahapan yaitu perencanaan, pelaksanaan, observasi dan refleksi. 


\section{Rancangan Penelitian}

Penelitian ini direncanakan dilaksanakan dalam dua siklus dan masing-masing siklus terdiri dari dua kali pertemuan.Untuk memperlancar jalannya penelitian, peneliti menyusun langkah-langkah penelitian yang terdiri dari perencanaan (plan), tindakan (action), observasi (observation) dan refleksi (reflection).

\section{HASIL PENELITIAN DAN PEMBAHASAN}

Pada bahasan ini akan diuraikan temuan peneliti yang telah dianalisisi dan dijelaskan sebelumnya. Dari hasil belajar atau ketuntasan belajar mulai dari tes awal, postes siklus I dan postes siklus II, terlihat adanya peningkatan yang baik dicapai siswa pada pretest awal, terdapat 27 siswa yang tidak tuntas dalam belajar $(96,43 \%)$ dan hanya 3 orang siswa yang tuntas $(3,57 \%)$.

\section{Hasil Belajar Siswa Pretest, Postes Siklus I, Postest Siklus II}

\begin{tabular}{|c|c|c|c|c|c|}
\hline \multirow[b]{2}{*}{$\mathrm{NO}$} & \multirow[b]{2}{*}{ Nama Siswa } & \multicolumn{2}{|c|}{ Nilai Siklus 1} & \multirow{2}{*}{$\begin{array}{l}\text { Nilai } \\
\text { Postes } \\
\text { Siklus II }\end{array}$} & \multirow[t]{2}{*}{ Keterangan } \\
\hline & & Pretes & Postes & & \\
\hline 1 & Agina Tarigan & 50 & 80 & 80 & Meningkat/Tuntas \\
\hline 2 & Amanda Sitepu & 60 & 80 & 90 & Meningkat/Tuntas \\
\hline 3 & Alexandro Sumbayak & 60 & 80 & 80 & Meningkat/Tuntas \\
\hline 4 & Bintang & 60 & 60 & 80 & Meningkat/Tuntas \\
\hline 5 & Ceisya Saragih & 60 & 70 & 80 & Meningkat/Tuntas \\
\hline 6 & Claudya & 60 & 80 & 90 & Meningkat/Tuntas \\
\hline 7 & David & 50 & 80 & 100 & Meningkat/Tuntas \\
\hline 8 & Dinda Sihotang & 50 & 80 & 80 & Meningkat/Tuntas \\
\hline 9 & Francois & 50 & 70 & 80 & Meningkat/Tuntas \\
\hline
\end{tabular}




\begin{tabular}{|c|c|c|c|c|c|}
\hline 10 & Grace Quin & 30 & 80 & 80 & Meningkat/Tuntas \\
\hline 11 & Inez & 50 & 60 & 80 & Meningkat/Tuntas \\
\hline 12 & Jonatan & 50 & 70 & 70 & Meningkat/ Tidak Tuntas \\
\hline 13 & Jovandra & 50 & 60 & 60 & Meningkat/ Tidak Tuntas \\
\hline 14 & Leo Nardo & 40 & 50 & 80 & Meningkat/Tuntas \\
\hline 15 & Marcello & 60 & 80 & 80 & Meningkat/Tuntas \\
\hline 16 & Mitra Judika & 40 & 40 & 70 & Meningkat/Tidak Tuntas \\
\hline 17 & Prada Ginting & 70 & 70 & 80 & Meningkat/Tuntas \\
\hline 18 & Raymon & 70 & 80 & 80 & Meningkat/Tuntas \\
\hline 19 & Rini Anastasya & 50 & 80 & 80 & Meningkat/Tuntas \\
\hline 20 & Ribery Sirait & 60 & 80 & 80 & Meningkat/Tuntas \\
\hline 21 & Shiren Melani Tiara & 30 & 60 & 80 & Meningkat/Tuntas \\
\hline 22 & Tiara & 60 & 80 & 80 & Meningkat/Tuntas \\
\hline 23 & Thomas & 50 & 60 & 100 & Meningkat/Tuntas \\
\hline 24 & Vania Nirwasty S & 80 & 90 & 90 & Meningkat/Tuntas \\
\hline 25 & Vanesa & 50 & 60 & 80 & Meningkat/Tuntas \\
\hline 26 & Vanesa Tobing & 70 & 80 & 80 & Meningkat/Tuntas \\
\hline 27 & Wiliam Jeremi & 60 & 60 & 100 & Meningkat/Tuntas \\
\hline 28 & Yohanes Eka P & 50 & 80 & 80 & Meningkat/Tuntas \\
\hline & $\sum X$ & 1520 & 1990 & 2290 & Meningkat \\
\hline & $X$ & 54,28 & 71,07 & 81,78 & Meningkat \\
\hline & $\mathrm{N}$ & 28 & 28 & 28 & \\
\hline
\end{tabular}

Dari tabel 4.12 di atas dapat disimpulkan bahwa siswa yang tuntas belajar pretes sebanyak 1 orang siswa $(3,57 \%)$ dan yang tidak tuntas sebanyak 27 orang siswa 
$(96,43 \%)$. Pada siklus 1 terdapat sebanyak 15(53,58\%) 0rang siswa yang tuntas dan yang tidak tuntas sebanyak $13(46,42 \%)$ orang siswa yang tidak tuntas. Untuk siklus II, diperoleh hasil belajar siswa pada postes dai 28 orang siswa terdapat sebanyak 25 $(89,29 \%)$ yang tuntas dan yang tidak tuntas sebanyak 3 Orang $(10,71 \%)$. Untuk lebih jelasnya peningkatan hasil belajar siswa secara klasikal dapat dilihat pada tabel 4.12 dibawah ini:

\section{Hasil Belajar Siswa Secara Klasikal}

\begin{tabular}{|l|l|l|}
\hline No & Jenis Tes & Presentase Ketuntasan Klasikal \\
\hline 1 & Pretes & $3,57 \%$ \\
\hline 2 & Postes Siklus I & $53,58 \%$ \\
\hline 3 & Postes Siklus II & $89,29 \%$ \\
\hline
\end{tabular}

Hasil ini menunjukkan bahwa nilai siswa meningkat dari dilaksanakan pretes sampai postes tiap siklus diperoleh peningkatan hasil belajar siswa pada materi upaya keseimbangan dan pelestarian sumber daya alam di lingkungannya. Lebih jelasnya peningkatan hasil belajar siswa dapat dilihat pada diagram dibawah ini: 


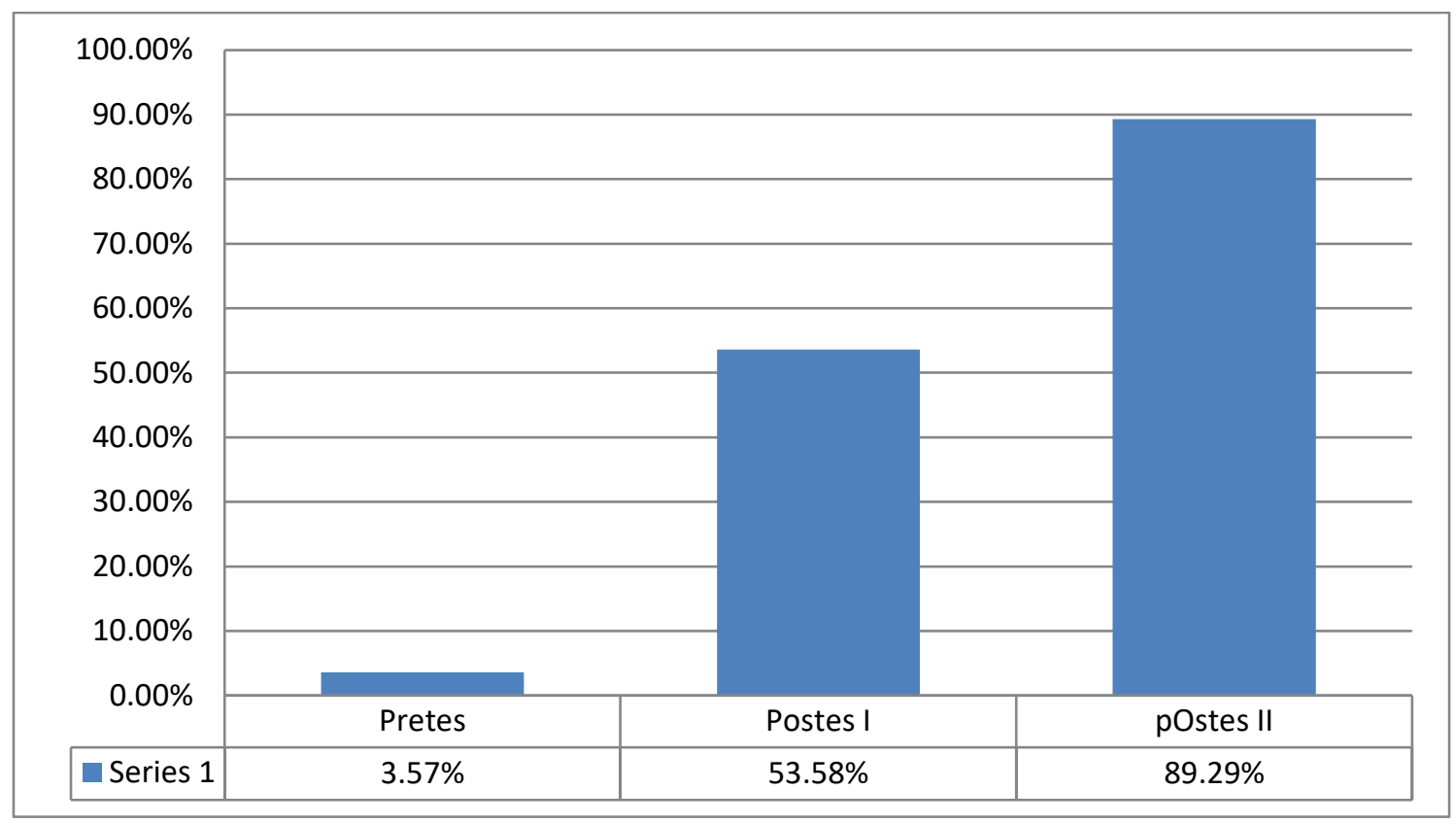

Diagram Peningkatan Ketuntasan Hasil Belajar Siswa

Dari di atas dapat dilihat bahwa terdapat peningkatan hasil belajar yang tinggi dari masing-masing diagram. Jadi dapat disimpulkan bahwa melalui temuan yang diperoleh memberikan jawaban terhadap hipotesis tindakan yang dikemukakan sebelumnya bahwa dengan menggunakan model pembelajaran Kooperatif tipe Course Review Horay (CRH) dapat meningkatkan hasil belajar.

\section{PENUTUP}

\section{Simpulan}

Berdasarkan hasil penelitian yan dilakukan oleh peneliti dengan menggunakan model pembelajaran Kooperatif tipe tipe Course Review Horay (CRH) pada materi upaya keseimbangan dan pelestarian sumber daya alam di lingkungannyapada siswa kelas IV-A SD Santo Petrus Jalan Luku 1 Medan pada mata pelajaran IPA semester ganjil tahun pembelajaran 2018/2019, maka dapat disimpulkan sebagai berikut:

1. Pada siswa kelas IV-A SD Santo Petrus Jalan Luku 1 Medan tahun pembelajaran 2018/2019 terjadi peningkatan yaitu dapat dibuktikan dengan 
meningkatnya hasil belajar siswa pada setiap siklus yaitu: pretes dengan nilai rata-rata adalah 54,28 pada siklus I meningkat dengan nilai rata-rata 71,07 setelah itu ketuntasan secara klasikal $(53,58 \%)$. Selanjutnya pada siklus II diperoleh nilai rata-rata sebesar 81,78 , yang berarti persentasi siswa yang mengalami perubahan sebesar $(89,29 \%)$ Hal ini menunjukkan terjadi peningkatan secara klasikal dari siklus I ke siklus II sebesar 35,71\%.

2. Aktivitas guru dalam pembelajaran IPA pada materi upaya keseimbangan dan pelestarian sumber daya alam di lingkungannya dengan menggunakan model pembelajaran Kooperatif tipe tipe Course Review Horay (CRH) terjadi peningkatan. Hal ini dapat dilihat berdasarkan nilai observasi untuk guru pada siklus $62 \%$ dalam lategori baik tapi belum mencapai indicator penelitian pada siklus II mengalami peningkatan menjadi $84 \%$ dalam lategori baik sekali dan sudah mencapai indicator penelitian.

3. Aktivitas siswa dalam pembelajaran IPA pada materi upaya keseimbangan dan pelestarian sumber daya alam di lingkungannya dengan menggunakan model pembelajaran Kooperatif tipe tipe Course Review Horay (CRH) terjadi peningkatan. Hal ini dapat dilihat berdasarkan nilai observasi untuk siswa pada siklus $70 \%$ dalam lategori baik tapi belum mencapai indicator penelitian pada siklus II mengalami peningkatan menjadi $80 \%$ dalam lategori baik sekali dan sudah mencapai indicator penelitian. 


\section{Saran}

Dari hasil penelitian dari kesimpulan di atas maka peneliti mengajukan beberapa saran sebagai berikut.

1. Sebagai bahan masukan bagi sekolah untuk menggunakan model pembelajaran Kooperatif tipe tipe Course Review Horay (CRH) dengan upaya keseimbangan dan pelestarian sumber daya alam di lingkungannya karena telah terbukti dapat meningkatkan hasil belajar siswa Kelas IV-A SD Santo Petrus Jalan Luku 1 Medan tahun pembelajaran 2018/2019.

2. Sebagai bahan masukan bagi semua guru agar dapat menggunakan model pembelajaran Kooperatif tipe tipe Course Review Horay (CRH).pada saat mengajar guna untuk meningkatkan hasil belajar siswa khususnya pada mata pelajaran IPA supaya dapat terlaksana dengan maksimal.

3. Bagi peneliti kiranya hasil penelitian tindakan kelas ini dapat dijadikan suatu model pembelajaran dalam pengajaran serta pengetahuan untuk menambah wawasan dan pemahaman mengenai penggunaan model pembelajaran dalam proses belajar mengajar nanti.

\section{DAFTAR PUSTAKA}

Arikunto. 2010. Prosedur Penelitian Suatu Pendekatan Praktik. Jakarta: PT Rineka Cipta.

Aqib, Zinal, dkk. 2016. Penelitian Tindakan Kelas. Bandung: Yrama Widya

Hamalik. 2013. Kurikulum dan Pembelajaran. Jakarta: PT Bumi Aksara. 2013. Proses Belajar Mengajar. Jakarta: PT Bumi Aksara.

Huda, Miftahul. 2014. Model-Model Pengajaran dan Pembelajaran. Yogyakarta: Pustaka Belajar.

Isjoni. 2011. Cooperative Learning. Bandung: Alfabeta. 
Istarani dan Intan Pulungan. 2016. Ensiklopedi Pendidikan. Medan: Larispa

Kurniasih dan Berlin Sani. 2016. Ragam Pengembangan Model Pembelajaran untuk Peningkatan Profesionalitas Guru. Jakarta: Pena.

Purwanto. 2017. Evaluasi Hasil Belajar. Yogyakarta: Pustaka Belajar.

Sardiman. 2014. Interaksi \& Motivasi Belajar Mengajar. Jakarta: PT Raja Grafindo Persada.

Shohimin, Aris. 2014. 68 Model Pembelajaran Inovatif dalam Kurukulum 2013. Yogyakarta: Ar-Ruzz Media

Sudjana, Nana. 2016. Penilaian Hasil Proses Belajar. Bandung: PT Remaja Rosdakarya.

Susanto, Ahmad. 2013. Teori Belajar dan Pembelajaran di Sekolah Dasar. Jakarta: Prenamedia Group.

Syah, Muhibbin. 2017 Psikoligi Belajar. Jakarta: PT Raja Grafindo Persada.

2017 Psikologi Pendidikan. Bandung: PT Remaja Rosdakarya Offiset.

Tampubolon, Saur.2014. Penelitian Tindakan Kelas untuk Pengembangan Profesi Pendidik dan Keilmuan. Jakarta: Erlangga

Trianto. 2016. Mendesain Model Pembelajarani -Inovatif-Progresif. Jakarta: PT Bumi Aksara

Wisudawati dan Eka Sulistyowati. 2014. Metodologi Pembelajaran IPA. Jakarta : PT. Bumi Aksara.

http://digilib.unimed.ac.id/6662/

https://ejournal.undiksha.ac.id/index.php/JJPGSD/article/view/2286

https://eprints.uns.ac.id/id/eprint/14357

http://eprints.umpo.ac.id/2146

https://lib.unnes.ac.id/21705/1/1401411573-s.p 